\title{
TUMPANGSARI SORGUM DAN KEDELAI UNTUK MENDUKUNG PRODUKTIVITAS LAHAN TBM KARET (HEVEA BRASILIENSIS MUELL ARG)
}

\author{
Intercropping of Sorghum and Soybean to Support Land Productivity of \\ Immature Rubber (Hevea brasiliensis Muell Arg) Plantations
}

\author{
Radite TISTAMA ${ }^{1 *}$, Cici Indriani DALIMUNTHE ${ }^{1)}$, Yan Riska Venata SEMBIRING ${ }^{11}$, Iif Rahmat \\ FAUZI $^{1}$, Ratih Dewi HASTUTI ${ }^{2}$, dan SUHARSONO ${ }^{3)}$ \\ ${ }^{1}$ Balai Penelitian Sungei Putih, Pusat Penelitian Karet \\ PO Box 1415 Medan 20001 Sumatera Utara \\ Email : raditetistama@yahoo.com \\ ${ }^{2}$ Pusat Penelitian Tanah \\ J1. Tentara Pelajar No. 12 Bogor 16114, Jawa Barat \\ ${ }^{3}$ Departemen Biologi, Fakultas MIPA, Institut Pertanian Bogor \\ Kampus IPB Dramaga Bogor 16680 Bogor Jawa Barat
}

Diterima : 6 Januari 2016 / Direvisi : 20 Juli 2016 / Disetujui : 30 Juli 2016

\begin{abstract}
Sorghum (Sorghum bicolor) and soybean (Glycine max) as intercrops are important to support the development of sustainable agriculture and increase food production in Indonesia. Immature rubber plantations are generally still have open space and potential to be used for growing intercrops. The objectives of the research were to get the best patterns of intercropping and to see the interactions between rubber and intercrops in the spread of white root disease and soil fertility change. Treatment factors were distance of intercrop to rubber plants and the kind of intercropping plant. This study was conducted in 1 year and 3 year of immature rubber area. This study was designed in a Randomized Block Design (RBD) with two treatments factors and three replications. The results showed that the intercrop distance of $0.5 \mathrm{~m}, 1 \mathrm{~m}$ and $1.5 \mathrm{~m}$ away from rubber trees had not significantly different in their effect on rubber growth. Sorghum and soybean intercropping increase soil $\mathrm{pH}$, phosphorous, nitrogen and $\mathrm{CEC}$ of the soil and also inhibited the spread of white root disease. The production of soybean and sorghum as intercroped plants were the best when the intercroped plant were grown up to $0.5 \mathrm{~m}$ distance from rubber trees and sorghum and soybean intercropping (Individually) on immature plant area of 1 year of age (IRP 1) could provide benefits or added value for farming.
\end{abstract}

Keywords: Hevea brasiliensis; intercropping; sorghum; soybean; land productivity.

Abstrak
Penanaman sorgum (Sorghum
bicolor) dan kedelai (Glycine max) sebagai
tanaman tumpangsari merupakan pilihan
yang tepat untuk mendukung upaya
pengembangan pertanian berkelanjutan dan
peningkatan produksi pangan Indonesia.
Lahan karet belum menghasilkan cukup
luas untuk dimanfaatkan untuk upaya
tersebut. Penelitian ini bertujuan untuk
mendapatkan pola tanam tumpangsari yang
tepat dan melihat interaksinya terhadap
tanaman karet baik dalam hal penyebaran
penyakit jamur akar putih dan kesuburan
tanah. Penelitian ini menggunakan
Rancangan Acak Kelompok (RAK) dengan
dua faktor perlakuan dengan tiga ulangan.
Faktor perlakuan yang digunakan yaitu
jarak tanaman tumpangsari 0,5 m, 1 m dan
1,5 m terhadap tanaman karet, dan jenis
tanaman tumpangsari yaitu sorgum dan
kedelai. Penelitian dilakukan di gawangan
tanaman karet umur 1 tahun (TBM 1) dan
umur 3 tahun (TBM 3). Hasil penelitian
menunjukkan bahwa pengaruh jarak
tanaman tumpangsari pada setiap
perlakuan tidak berbeda nyata terhadap
pertumbuhan tanaman karet. Tanaman


tumpangsari sorgum dan kedelai meningkatkan $\mathrm{pH}$, fosfor, nitrogen, dan kapasitas tukar kation (KTK) di dalam tanah, serta dapat menekan penyebaran penyakit Jamur Akar Putih (JAP). Produksi tumpangsari menunjukkan pola tanam kedelai dan sorgum terbaik pada jarak tanam 0,5 $\mathrm{m}$ dari tanaman karet dan tumpangsari sorgum dan kedelai (tunggal) pada TBM 1 dapat memberikan keuntungan serta nilai tambah bagi usahatani karet.

Kata kunci: Hevea brasiliensis; tumpangsari; sorgum; kedelai; produktivitas lahan.

\section{PENDAHULUAN}

Perkebunan karet di Indonesia memiliki luas 3,4 juta Ha yang terdiri dari karet rakyat, kebun milik negara dan kebun swasta. Setiap tahun jumlah program peremajaan kebun karet rakyat berkisar 5070 ribu Ha (Supriadi, 2009), sedangkan program peremajaan tanaman karet di salah satu kebun milik negara di Sumatra Utara mencapai rata-rata $2500 \mathrm{Ha} /$ tahun. Selama tiga tahun setelah penanaman, areal perkebunan karet masih terbuka dan secara umum belum dimanfaatkan secara optimal. Di perkebunan besar, gawangan antar tanaman utama ditanami dengan tanaman kacangan seperti Mucuna bracteata untuk menekan gulma dan meningkatkan kesuburan tanah. Areal yang luas dan terbuka ini potensial untuk mendapatkan nilai tambah bagi petani selama tanaman belum menghasilkan (TBM).

Areal perkebunan karet yang belum menghasilkan dapat dimanfaatkan petani untuk bertanam tanaman pangan. Hal tersebut akan memberi nilai tambah bagi petani sebelum tanaman karet dapat dipanen lateksnya. Agar mendapatkan keuntungan yang optimal maka pemanfaatan gawangan kebun karet setidaknya perlu memperhatikan dua aspek yaitu tanaman sela (tumpangsari) mempunyai nilai ekonomis tinggi dan dapat memberi manfaat bagi tanaman utamanya. Komoditas tanaman pangan mempunyai kriteria tersebut seperti sorgum (Sorghum bicolor) dan kedelai (Glycine max).
Beberapa tahun terakhir ini permintaan pasar terhadap kedelai terus meningkat. Kedelai merupakan salah satu bahan pangan yang menjadi sumber protein nabati tinggi dan digunakan sebagai bahan baku dalam industri pangan dan industri pakan ternak. Namun pengembangan kedelai secara nasional terkendala oleh keterbatasan lahan. Selain kedelai, sorgum juga merupakan bahan pangan yang potensial untuk dikembangkan di areal perkebunan. Sorgum sangat tahan kondisi lahan kering karena domestikasinya memang berasal dari Afrika yang beriklim kering atau semi-arid (Toure \& Weltzien, 2004; Borrell et al., 2005). Sorgum yang dapat digunakan sebagai pangan, pakan ternak dan bioenergi (bioetanol), mampu beradaptasi pada kondisi lahan marginal dan membutuhkan air relatif lebih sedikit (lebih tahan terhadap kekeringan dibanding tanaman pangan lain). Areal perkebunan yang cukup luas merupakan potensi untuk dilakukannya ekstensifikasi pertanaman kedelai dan sorgum melalui sistem tumpangsari.

Penanaman kedelai dan sorgum sebagai tumpangsari menjadi pilihan dalam mendukung upaya pengembangan pertanian berkelanjutan dan peningkatan produksi pangan Indonesia. Sorgum dan kedelai selain bernilai ekonomis tinggi juga berfungsi meningkatkan produktivitas lahan kering marginal melalui perbaikan biologi tanah oleh mikoriza yang bersimbiosis dengan sorgum dan Rhizobium sp yang bersimbiosis dengan kedelai (Watkins, Castlehouse, Hannah, \& Nash, 2012). Kandungan fosfor (P) yang tersedia di dalam rhizosfer tanaman sorgum meningkat dengan pemberian inokulum mikoriza (Sawers, Yang, Gutjahn, \& Paszkowski, 2008). Di samping itu, beberapa penelitian juga menyebutkan bahwa penanaman tanaman kacangan membantu meningkatkan nitrogen $(\mathrm{N})$ di dalam tanah (Zahran, 1999). Dengan demikian kedua komoditas tersebut turut berperan dalam membantu menyediakan unsur hara penting yaitu fosfor $(\mathrm{P})$ dan nitrogen $(\mathrm{N})$. Sumbangan unsur hara tersebut ke tanah dapat mengurangi pemakaian pupuk kimia.

Penelitian ini bertujuan untuk mendapatkan pola tanam tumpangsari yang tepat dan melihat interaksinya terkait 
efektivitas tumpangsari sorgum dan kedelai terhadap ketersediaan fosfor dan nitrogen dalam meningkatkan pertumbuhan karet dan menekan perkembangan inokulum penyakit Jamur Akar Putih (JAP) pada tanaman karet belum menghasilkan (TBM karet).

\section{BAHAN DAN METODE}

Penelitian ini dilaksanakan pada bulan Februari - Desember 2013. Lokasi penelitian dilakukan di Kebun Percobaan Balai Penelitian Sungei Putih dan Laboratorium Tanah di Pusat Penelitian Tanah, Bogor. Bahan tanam yang digunakan dalam penelitian ini adalah tanaman kedelai yang toleran terhadap aluminium yang merupakan hasil perakitan Prof. Dr. Suharsono, DEA dari Institut Pertanian Bogor dan sorgum varietas Kawali sebagai tanaman sela di gawangan TBM karet.

Penelitian ini menggunakan Rancangan Acak Kelompok (RAK) dengan 2 faktor perlakuan dengan 3 ulangan. Faktor perlakuan yang digunakan yaitu jarak antar tanaman tumpangsari terhadap tanaman karet $(\mathrm{J})$, dan perlakuan jenis tanaman tumpangsari (P). Percobaan tersebut dilakukan di gawangan tanaman karet belum menghasilkan umur 1 tahun (TBM 1) dan umur 3 tahun (TBM 3). Sistem penanaman menggunakan sistem baris (row) dimana setiap perlakuan terdiri dari 5 baris dalam satu ulangan. Perlakuan yang digunakan dari setiap faktor terdapat pada Tabel 1.

Gawangan karet TBM 1 dan TBM 3 diolah dua minggu sebelum tanam dengan sistem luku dan garu (Gambar 1). Setelah diolah, tanah gawangan karet diberi pupuk kandang 5 ton/Ha untuk lahan sorgum dan 3 ton/Ha untuk lahan kedelai dengan cara ditebar. Jarak tanam yang digunakan untuk tanaman kedelai adalah $30 \times 20 \mathrm{~cm}$ sedangkan sorgum 40 × $20 \mathrm{~cm}$. Setelah itu biji ditanam dengan cara tugal. Setiap lubang tanam diisi sebanyak 3 butir, kemudian diberikan Furadan untuk mencegah serangan hama dan penyakit tanaman. Penjarangan dilakukan pada saat tanaman berumur 10-15 hari setelah tanam dengan memilih dua tanaman setiap lubang untuk dipelihara. Waktu tanam kedelai dan sorgum pada bulan April - September 2013. Pengambilan sampel tanah di areal TBM 1 dan TBM 3 untuk analisis kadar hara tanah dilakukan sebelum dan setelah penanaman sorgum dan kedelai. Analisis kimia tanah meliputi kandungan unsur hara nitrogen $(\mathrm{N})$, fosfor $(\mathrm{P})$, kalium $(\mathrm{K})$, dan magnesium (Mg), $\mathrm{pH}$ dan kapasitas tukar kation (KTK) dilakukan di Balai Penelitian Tanah, Bogor.

Pemeliharaan tanaman karet dilakukan sesuai norma kultur teknis yang berlaku di lokasi penelitian Kebun Percobaan Balai Penelitian Sungei Putih. Sedangkan pemeliharaan untuk tanaman tumpangsari meliputi penyulaman, penyiraman, pemupukan, dan pengendalian

Tabel 1. Rancangan percobaan tumpangsari kedelai (P1), sorgum (P2) dan kombinasi keduanya (P3) pada gawangan tanaman karet TBM 1 dan TBM 3 dengan jarak tanam 0,5 m (J1), $1 \mathrm{~m}$ (J2) dan 1,5 m (J3) dan areal gawangan yang tidak ditanami sebagai kontrol.

Table 1. Experimental design of intercrop soybean (P1), sorghum (P2) and the both combination (P3) in immature rubber plant (IRP 1 and IRP 3) with intercrop distances $0.5 \mathrm{~m}(\mathrm{~J} 1), 1$ $m(\mathrm{~J} 2)$ and $1.5 \mathrm{~m}(\mathrm{~J} 3)$, and space area which absent intercropping as control.

\begin{tabular}{|c|c|c|c|c|c|c|}
\hline \multirow[t]{2}{*}{$\begin{array}{l}\text { Perlakuan } \\
\text { Treatments }\end{array}$} & \multicolumn{3}{|c|}{$\begin{array}{c}\text { Jarak antara tanaman } \\
\text { tumpangsari dengan tanaman } \\
\text { karet TBM } 1 \\
\text { Distance of intercropping to rubber } \\
\text { tree of Immature rubber year } 1\end{array}$} & \multicolumn{3}{|c|}{$\begin{array}{c}\text { Jarak antara tanaman } \\
\text { tumpangsari dengan tanaman } \\
\text { karet TBM } 3 \\
\text { Distance of intercropping to } \\
\text { rubber tree of Immature rubber year } 3 \\
\end{array}$} \\
\hline & $\begin{array}{c}0,5 \mathrm{~m} \\
\left(\mathrm{~J}_{1}\right)\end{array}$ & $\begin{array}{l}1 \mathrm{~m} \\
\left(\mathrm{~J}_{2}\right)\end{array}$ & $\begin{array}{c}1,5 \mathrm{~m} \\
\left(\mathrm{~J}_{3}\right)\end{array}$ & $0,5 \mathrm{~m}\left(\mathrm{~J}_{1}\right)$ & $1 \mathrm{~m}\left(\mathrm{~J}_{2}\right)$ & $1,5 \mathrm{~m}\left(\mathrm{~J}_{3}\right)$ \\
\hline Kedelai (soybean) $\left(\mathrm{P}_{1}\right)$ & $\mathrm{P}_{1} \mathrm{~J}_{1}$ & $\mathrm{P}_{1} \mathrm{~J}_{2}$ & $\mathrm{P}_{1} \mathrm{~J}_{3}$ & $\mathrm{P}_{1} \mathrm{~J}_{1}$ & $\mathrm{P}_{1} \mathrm{~J}_{2}$ & $\mathrm{P}_{1} \mathrm{~J}_{3}$ \\
\hline Sorgum (sorghum) $\left(\mathrm{P}_{2}\right)$ & $\mathrm{P}_{2} \mathrm{~J}_{1}$ & $\mathrm{P}_{2} \mathrm{~J}_{2}$ & $\mathrm{P}_{2} \mathrm{~J}_{3}$ & $\mathrm{P}_{2} \mathrm{~J}_{1}$ & $\mathrm{P}_{2} \mathrm{~J}_{2}$ & $\mathrm{P}_{2} \mathrm{~J}_{3}$ \\
\hline $\begin{array}{l}\text { Kombinasi (combination } \\
\text { of both) }\left(\mathrm{P}_{3}\right)\end{array}$ & $\mathrm{P}_{3} \mathrm{~J}_{1}$ & $\mathrm{P}_{3} \mathrm{~J}_{2}$ & $\mathrm{P}_{3} \mathrm{~J}_{3}$ & $\mathrm{P}_{3} \mathrm{~J}_{1}$ & $\mathrm{P}_{3} \mathrm{~J}_{2}$ & $\mathrm{P}_{3} \mathrm{~J}_{3}$ \\
\hline Kontrol (control) $\left(\mathrm{P}_{4}\right)$ & & $\mathrm{P}_{4}$ & & & $\mathrm{P}_{4}$ & \\
\hline
\end{tabular}



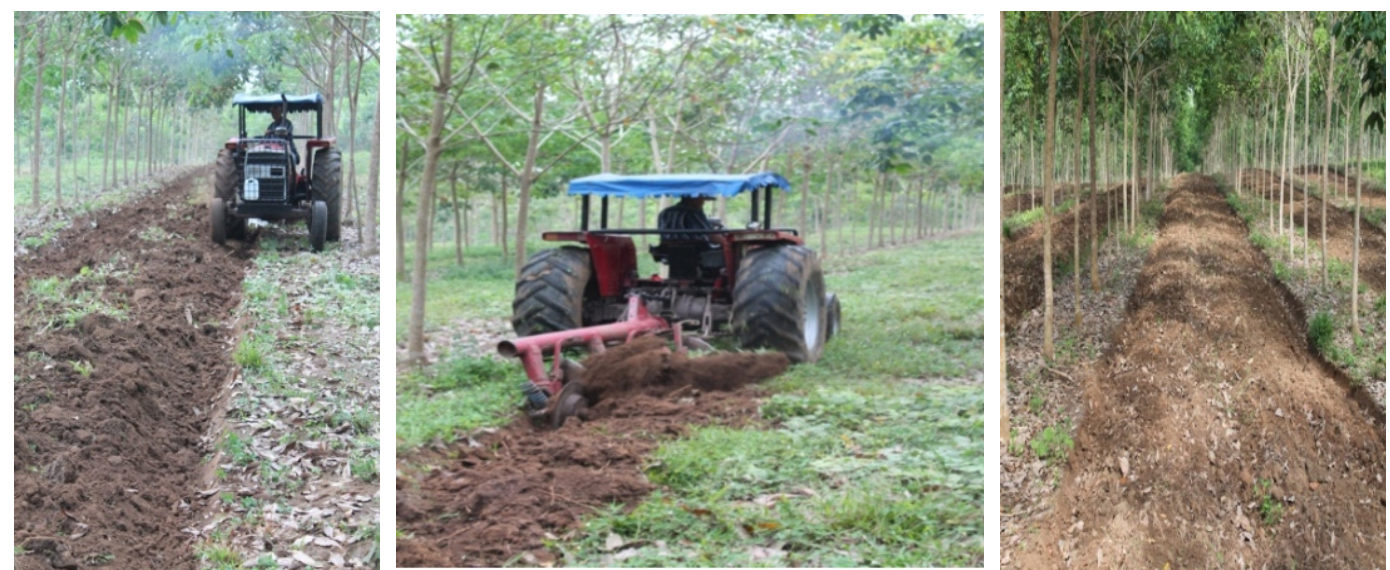

Gambar 1. Pengolahan tanah di gawangan TBM 3

Figure 1. Tillage in the space of Immature Rubber year 3

hama penyakit tanaman. Untuk pemupukan tanaman kedelai, diberikan urea, SP36, dan $\mathrm{KCl}$ masing-masing 25, 100, dan $75 \mathrm{~kg} / \mathrm{Ha}$ pada saat tanaman berumur 7 hari setelah tanam, dan disusul urea $25 \mathrm{~kg} / \mathrm{Ha}$ pada saat tanaman berumur 21 hari setelah tanam. Pupuk diberikan secara larikan 5-7 cm dari barisan tanaman. Sedangkan untuk pemupukan tanaman sorgum mengikuti dosis yang dianjurkan yaitu $200 \mathrm{~kg} /$ Ha urea, $100 \mathrm{~kg} / \mathrm{Ha}$ SP36, dan $50 \mathrm{~kg} / \mathrm{Ha}$ KCl. Pupuk diberikan secara larikan 5-7 cm dari barisan tanaman.

Parameter yang diamati adalah diameter batang TBM 1 dan TBM 3 yang diukur menggunakan meteran yang disesuaikan dengan kondisi tanaman dan konsisten terhadap titik pengukuran. Interval pengamatan dilakukan sebulan sekali setelah penanaman tumpangsari. Sedangkan pada parameter tanaman tumpangsari yang diamati adalah tinggi tanaman, bobot basah dan bobot kering. Tinggi tanaman kedelai dan sorgum diukur dari leher akar sampai pada bagian tumbuhnya daun paling muda. Pengamatan dimulai satu minggu setelah tanam sampai 90 hari setelah tanam dengan interval dua minggu sekali. Pengamatan bobot kering dan bobot basah tanaman tumpangsari dilakukan setelah penelitian berakhir (masa panen).

Pengamatan intensitas serangan JAP dilakukan sebelum dan sesudah penanaman tumpangsari. Pengamatan dilakukan intens dengan interval satu bulan sekali dengan cara membuka tanah di sekitar leher akar tanaman karet untuk mengetahui kategori nilai serangan. Nilai kategori serangan menurut Rahayu, Pawirosoemardjo, dan Sujatno (2007) adalah sebagai berikut:

\begin{tabular}{|c|c|}
\hline Skala 0 & $\begin{aligned} &= \text { akar tanaman terbebas dari } \\
& \text { serangan } R \text { microporus }\end{aligned}$ \\
\hline Skala 1 & $\begin{aligned}= & \text { akar tanaman ditumbuhi } \\
& \text { miselium } R \text {. microporus tetapi } \\
& \text { terbatas pada permukaan } \\
& \text { kulit }\end{aligned}$ \\
\hline Skala 2 & $\begin{aligned} &= \text { miselium telah melekat kuat } \\
& \text { pada kulit dan diperkirakan } \\
& \text { sebagian miselium R. } \\
& \text { Microporus telah masuk ke } \\
& \text { kayu }\end{aligned}$ \\
\hline Skala 3 & $\begin{aligned}= & \text { bagian kulit dan kayu telah } \\
& \text { membusuk }\end{aligned}$ \\
\hline & $=$ tanaman mati \\
\hline
\end{tabular}

Setelah mengetahui nilai kategori serangan, kemudian ditentukan intensitas serangan R. microporus dalam Fairuzah, Dalimunthe, Karyudi, Suryaman, dan Widhayati (2014) menggunakan rumus sebagai berikut:

$$
\mathrm{I}=\frac{\mathrm{n \times V}}{\mathrm{N} \times \mathrm{Z}} \times 100 \%
$$

Keterangan (Remaks):

I = intensitas serangan

$\mathrm{n}=$ jumlah akar tanaman sakit dari setiap kategori serangan

$\mathrm{V}$ = nilai skala dari setiap kategori serangan

$Z$ =nilai skala dari kategori serangan tertinggi

$\mathrm{N}=$ jumlah tanaman yang diamati 
Data yang diperoleh dari parameter yang telah ditentukan akan dianalisis ANOVA dan dilanjutkan dengan Duncan Multiple Range Test pada taraf kepercayaan $5 \%$.

Untuk mengetahui alternatif perlakuan yang paling efisien dan terbesar perolehan keuntungannya, dilakukan metode tabulasi yang kemudian disajikan secara diskriptif. Tingkat keuntungan dari masing-masing pola dihitung melalui analisis input-output yang secara matematis dirumuskan sebagai berikut:

$$
P=\sum_{t=1}^{n} B t-\sum_{t=1}^{n} C t
$$

Keterangan (Remaks) :

$\mathrm{P}=$ Pendapatan

$\mathrm{B}=$ Penerimaan

$\mathrm{C}=$ Biaya produksi

$\mathrm{t}=$ Waktu satu periode produksi

Untuk mengetahui perlakuan yang paling layak maka dilakukan analisis kriteria kelayakan finansial $\mathrm{R} / \mathrm{C}$ ratio yang secara matematis dapat dirumuskan sebagai berikut (Jumingan, 2011) :

$$
\frac{\sum_{t=1}^{7 n} B t}{\sum_{t=1}^{n} C t}
$$

Apabila $\mathrm{R} / \mathrm{C}$ ratio $>1$, maka usahatani tersebut layak dilakukan.

\section{HASIL DAN PEMBAHASAN}

\section{Pengaruh Tumpangsari Kedelai dan Sorgum terhadap Pertumbuhan Tanaman Karet}

Tanaman tumpangsari kedelai dan sorgum di gawangan memberikan pengaruh positif terhadap pertumbuhan tanaman utama (karet) berupa pertambahan lilit batang baik pada TBM 1 maupun TBM 3 (Gambar 2). Tumpangsari pada TBM 1 dengan jarak tanam $1 \mathrm{~m}$ dari tanaman karet memberikan dukungan pertumbuhan karet paling optimal bila dibandingkan jarak tanam $0,5 \mathrm{~m}$ atau $1,5 \mathrm{~m}$. Sama halnya dengan tumpangsari di TBM 3 tetap memberikan pengaruh positif terhadap pertambahan lilit batang karet. Hasil penelitian menunjukkan ada perbedaan yang nyata untuk setiap perlakuan jarak tanam terhadap kontrol (tanpa tumpangsari), sedangkan pada setiap perlakuan jarak tanam tidak menunjukkan perbedaan yang nyata. Hal ini sesuai dengan pernyataan Ogwuche, Umar, Esekhade, dan Franscis (2012) bahwa tumpangsari ubi rambat, kacang panjang dan cabai dapat meningkatkan pertumbuhan karet dan lebih cepat mencapai matang sadap dibandingkan tanaman karet tanpa tumpangsari. Sistem tumpangsari juga membantu pertumbuhan karet terutama di areal-areal rehabilitasi (Idoko, Ehigiator, Esekhade, \& Orimoloyo 2012).

Proses pengolahan lahan secara mekanis yang dikhawatirkan merusak perakaran dan menghambat pertumbuhan tanaman karet tidak terjadi. Hal ini disebabkan ada dua faktor yaitu pertama fungsi penyerapan hara dicukupi oleh perakaran di barisan, kedua kerusakan akar digantikan dengan akar baru yang dapat dengan mudah menyebar karena kondisi tanah yang gembur. Rambut akar merupakan sentral penyerapan nutrisi dari tanah yang permukaannya meliputi $60 \%$ dari permukaan akar (Giehl \& Von Wiren, 2014). Penyebaran akar hara secara horizontal pada tanaman karet TBM 1 tahun masih berada di $50 \mathrm{~cm}$ dari pohon. Pertumbuhan karet didukung oleh tersedianya residu pupuk yang tidak diserap oleh akar tumpangsari dan kemungkinan adanya peningkatan aktivitas mikroba tanah. Nugroho, Istianto, Siagian, dan Karyudi (2010) melaporkan bahwa di areal gawangan yang tertutup kacangan menjadi lebih lembab karena aktivitas mikroba tanah meningkat. Kelembaban tanah membantu akar dalam menyerap hara dengan dibantu oleh aktivitas mikroba di sekitar perakaran.

\section{Intensitas Penyebaran Jamur Akar Putih pada Tanaman Karet}

Selama 3 bulan penanaman tumpangsari, areal gawangan maupun akar TBM 1 tidak ditemukan serangan inokulum JAP. Hal ini sangat erat kaitannya dengan pengolahan mekanis di TBM 1 terutama kegiatan ayap akar yang dapat menjadi sumber infeksi JAP. Tingkat serangan pada TBM 3 sebelum penanaman tumpangsari 

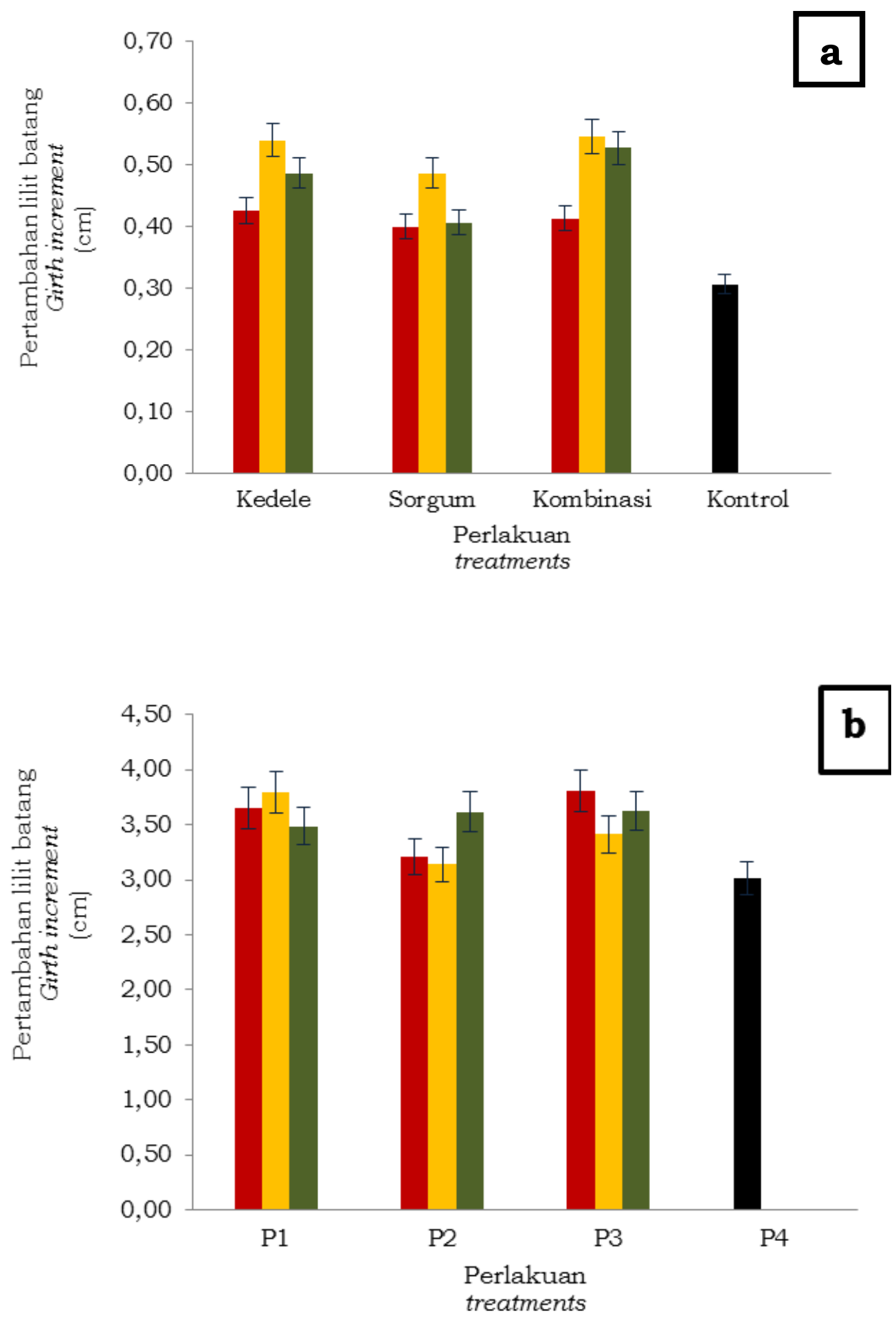

Gambar 2. Pertambahan lilit batang karet pada tumpangsari di TBM 1 (a) dan lilit batang karet pada tumpangsari di TBM 3 (b) dengan tumpangsari berumur 3 bulan.

Figure 2. Increments of rubber tree girth in intercropping at Immature Rubber Plant Immature Rubber year1 and 1 (a), and rubber tree girth in intercropping at Immature Rubber year $3(b)$ 
berkisar $0,0-8,33 \%$. Seperti halnya tumpangsari TBM 1, populasi JAP di TBM 3 hampir tidak ada peningkatan, walaupun juga tidak ada indikasi penurunan populasi JAP. Pada areal yang tidak ditanami tumpangsari terjadi peningkatan perkembangan JAP dari 3,33\% menjadi 5\% atau dari skala 1 menjadi skala 2 (Tabel 2).

Penghambatan perkembangan JAP berkaitan erat dengan kedelai dan sorgum sebagai tumpangsari. Tanaman kedelai dan sorgum diduga meningkatkan aktivitas mikrobia-mikrobia tanah yang secara alami berkompetisi dengan JAP, dan kedua tanaman tersebut bukan merupakan inang bagi JAP. Rhizobium japonicum pada tanaman kedelai dapat mengurangi serangan penyakit akar. Kelembaban tanah yang tinggi akan meningkat populasi bakteri atau jamur yang bersifat antagonis terhadap jamur akar putih atau meningkatkan ketahanan akar terhadap serangan penyakit (Nugroho et al., 2010). Bakteri rhizosfer Pseudomonas flourescens mengkoloni akar kacang tanah dan menginduksi sistem pertahanan tanaman kacang tersebut (Benhamou, Belanger, \& Paulitz, 1996). Selain itu Pseudomonas flourescens juga dapat menekan pertumbuhan penyakit akar pada tanaman buah dengan menghasilkan senyawa 2-Hexyl 5-propyl resorcinol (Cazorla et al., 2006).

Sorgum adalah salah satu inang mikoriza dan dari percobaan sebelumnya terbukti bahwa penanaman sorgum meningkatkan jumlah spora mikoriza. Mikoriza dilaporkan dapat mengendalikan penyakit akar serta mengurangi pengaruh cekaman hara atau keracunan tanah (Martin et al., 2007; Linderman 1996). Inokulasi mikoriza pada akar tanaman karet diketahui mengurangi infeksi jamur akar putih (Jayaratna, Liyanage, \& Pahalawattaarachchi, 1986). Selain itu, kolonisasi akar oleh mikoriza meningkatkan kandungan asam salisilat pada jaringan akar. Asam salisilat tersebut berperan dalam sistem pertahanan tanaman terhadap serangan beberapa penyakit (Khaosaad, Garcia-Garrido, Steinkellner, \& Vierheilig, 2007).

\section{Pertumbuhan tanaman tumpangsari di gawangan karet}

Hasil penelitian menunjukkan bahwa pertumbuhan sorgum dan kedelai normal di TBM 1, sedangkan pada perlakuan kombinasi pertumbuhan kedelai terganggu karena naungan dari tanaman sorgum. Sama halnya dengan tanaman kedelai di TBM 3 yang mengalami etiolasi, warna daun kekuningan dan pembentukan polong

Tabel 2. Intensitas serangan jamur akar putih (JAP) di TBM 3

Table 2.Intensity of white root disease infection in Immature Rubber year 3

\begin{tabular}{|c|c|c|}
\hline \multirow{2}{*}{$\begin{array}{l}\text { Perlakuan } \\
\text { Treatments }\end{array}$} & \multicolumn{2}{|c|}{$\begin{array}{c}\text { Intensitas serangan Jamur Akar Putih } \\
\text { Infection of White Root Disease } \\
(\%)\end{array}$} \\
\hline & $\begin{array}{l}\text { Pre perlakuan } \\
\text { Pre treatments }\end{array}$ & $\begin{array}{c}\text { Setelah perlakuan } \\
\text { Post treatment }\end{array}$ \\
\hline $\mathrm{P} 1 \mathrm{~J} 1$ & 8,33 & 8,33 \\
\hline $\mathrm{P} 1 \mathrm{~J} 2$ & 1,67 & 1,67 \\
\hline P1J3 & 1,67 & 1,67 \\
\hline P2J 1 & 5,00 & 5,00 \\
\hline P2J2 & 0,00 & 0,00 \\
\hline P2J3 & 3,33 & 3,33 \\
\hline P3J 1 & 3,33 & 3,33 \\
\hline P3J2 & 1,67 & 1,67 \\
\hline P3J3 & 0,00 & 0,00 \\
\hline P4 & 3,33 & 5,00 \\
\hline
\end{tabular}




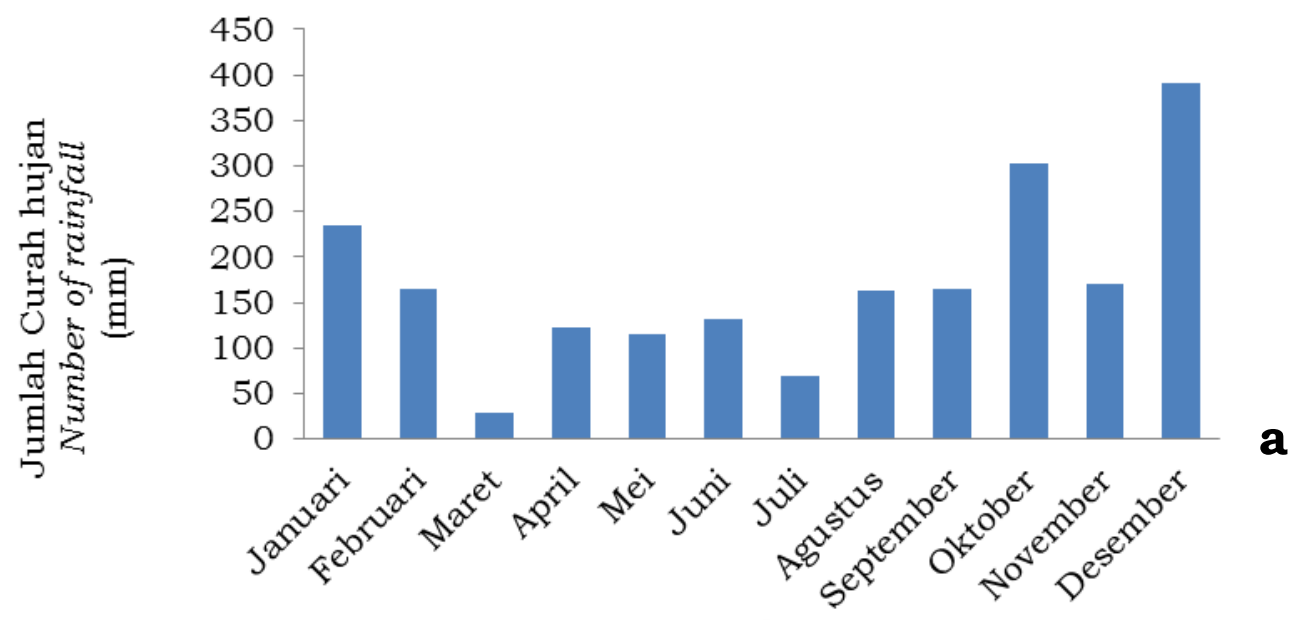

Bulan

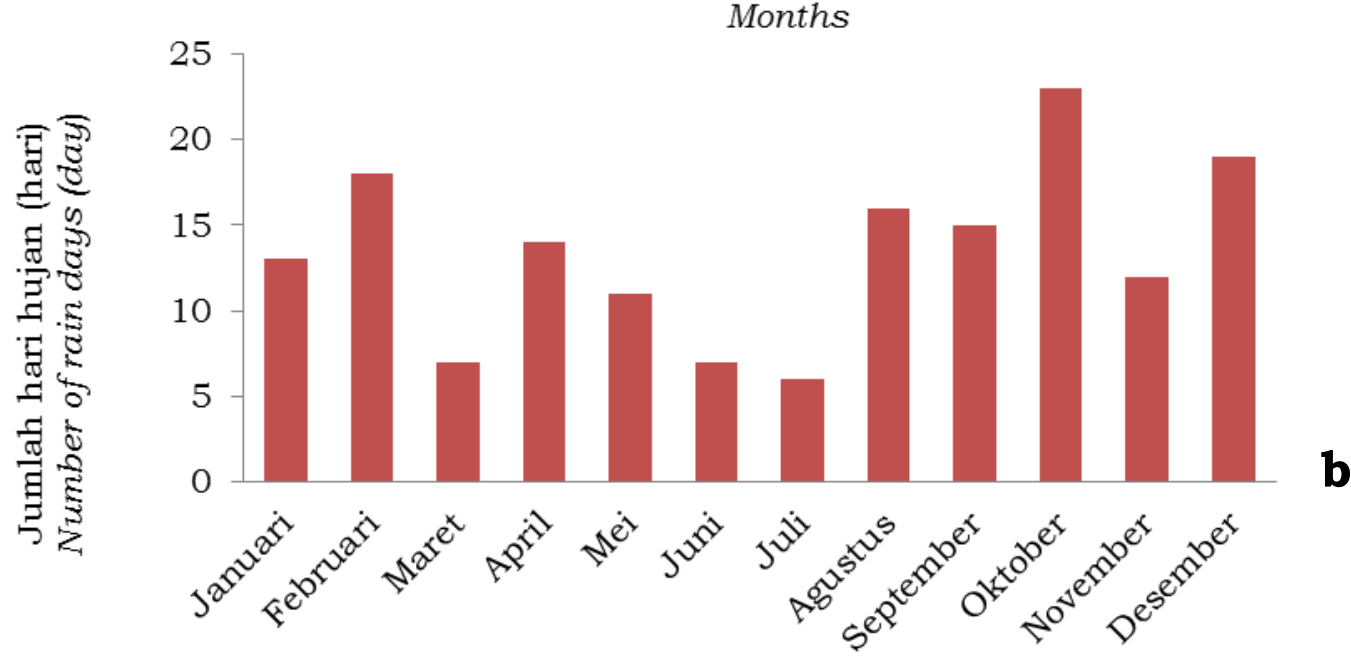

Bulan

Months

Gambar 3. Jumlah curah hujan (a) dan hari hujan (b) kebun Balai Penelitian Sungei Putih tahun 2013

Figure 3. The amount of rainfall (a) and the number of rain days (b) at the Sungei Putih Research Center in 2013

Tabel 3. Tinggi tanaman tumpang sari pada TBM 1

Table 3. Height intercropping plant in Immature Rubber at year 1

\begin{tabular}{|c|c|c|c|c|}
\hline \multirow{2}{*}{$\begin{array}{l}\text { Perlakuan } \\
\text { Treatments }\end{array}$} & \multirow{2}{*}{$\begin{array}{l}\text { Sorgum } \\
\text { Sorghum }\end{array}$} & \multirow{2}{*}{$\begin{array}{l}\text { Kedelai } \\
\text { Soybean }\end{array}$} & \multicolumn{2}{|c|}{$\begin{array}{l}\text { Kombinasi } \\
\text { Combination }\end{array}$} \\
\hline & & & $\begin{array}{l}\text { Sorgum } \\
\text { Sorghum }\end{array}$ & $\begin{array}{c}\text { Kedelai } \\
\text { Soybean }\end{array}$ \\
\hline 0,5 & $171,23 \mathrm{c}$ & $46,30 \mathrm{a}$ & $179,13 \mathrm{~b}$ & $7,27 \mathrm{a}$ \\
\hline 1 & $169,01 \mathrm{~b}$ & $45,48 \mathrm{a}$ & $165,26 \mathrm{a}$ & $9,21 \mathrm{~b}$ \\
\hline 1,5 & $159,68 \mathrm{a}$ & 44,79 a & $184,19 \mathrm{c}$ & $10,96 \mathrm{c}$ \\
\hline
\end{tabular}

Angka-angka yang diikuti oleh huruf yang berbeda pada kolom yang sama berbeda nyata pada Uji Jarak Berganda Duncan pada taraf $5 \%$

Figures followed by different letter in the same column are significantly different based on Duncan multiple range test at $5 \%$ significant level 
Tabel 4. Tinggi tanaman tumpang sari pada TBM 3

Table 4. Height intercropping plant in Immature Rubber at year 3

\begin{tabular}{ccccc}
\hline \multirow{2}{*}{$\begin{array}{c}\text { Perlakuan } \\
\text { Treatments }\end{array}$} & Sorgum & Kedelai & \multicolumn{2}{c}{$\begin{array}{c}\text { Kombinasi } \\
\text { Combination }\end{array}$} \\
\cline { 4 - 5 } & Sorghum & Soybean & $\begin{array}{c}\text { Sorgum } \\
\text { Sorghum }\end{array}$ & $\begin{array}{c}\text { Kedelai } \\
\text { Soybean }\end{array}$ \\
\hline 0,5 & $94,58 \mathrm{a}$ & $84,96 \mathrm{c}$ & $125,74 \mathrm{ab}$ & $66,55 \mathrm{~b}$ \\
1 & $93,28 \mathrm{ab}$ & $55,60 \mathrm{~b}$ & $123,34 \mathrm{abc}$ & $65,78 \mathrm{~b}$ \\
1,5 & $93,10 \mathrm{~b}$ & $51,92 \mathrm{~b}$ & $115,66 \mathrm{a}$ & $59,09 \mathrm{~b}$ \\
\hline
\end{tabular}

Angka-angka yang diikuti oleh huruf yang berbeda pada kolom yang sama berbeda nyata pada Uji Jarak Berganda Duncan pada taraf $5 \%$

Figures followed by different letter in the same column are significantly different based on Duncan multiple range test at $5 \%$ significant level
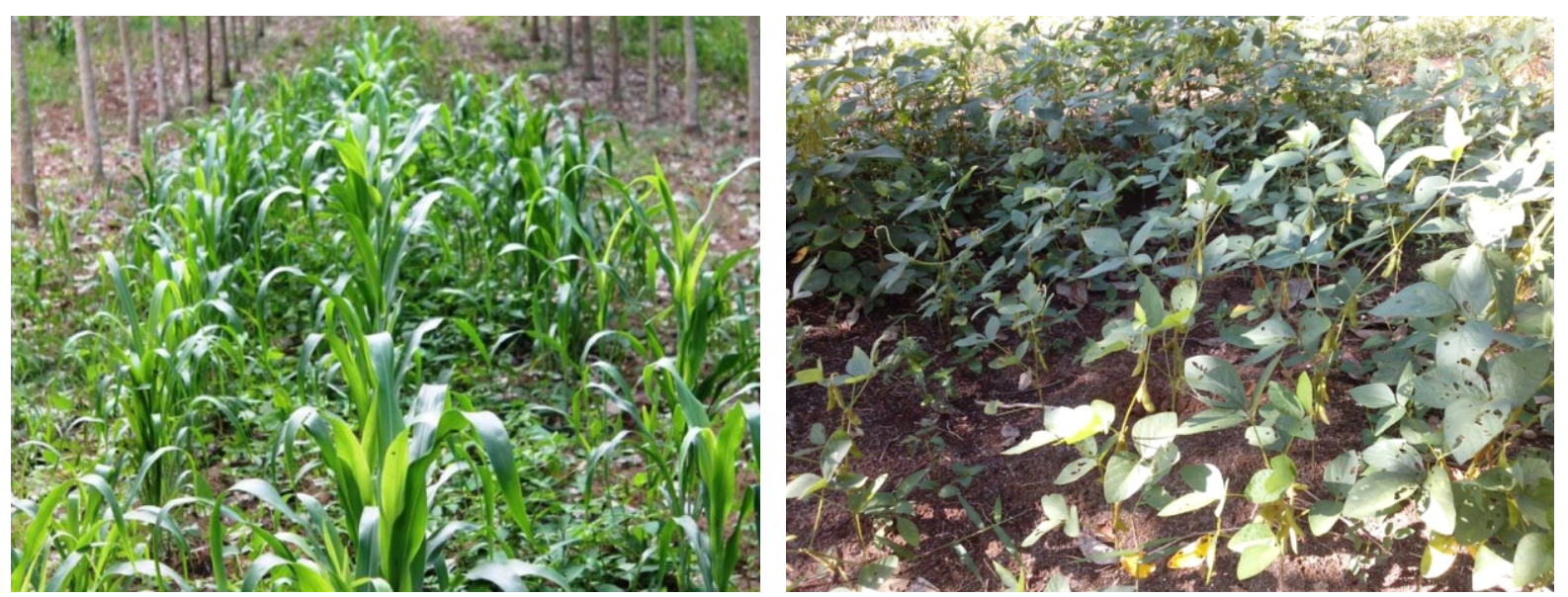

Gambar 4. Tanaman tumpangsari kedelaidan sorgum di gawangan TBM 3

Figure 4. Intercropping soybean and sorghum in the space of Immature Rubber year 3

terganggu (Gambar 4). Tanaman sorgum juga mengalami penghambatan pertumbuhan sehingga tinggi tanamannya hanya sepertiga dari pertumbuhan tanaman di TBM 1. Pertumbuhan terhambat disebabkan karena tajuk tanaman karet yang sudah mulai menutupi areal gawangan, sehingga intensitas cahaya matahari terbatas dan fotosintesis terhambat.

Pada TBM 1, tinggi tanaman tumpangsari sorgum berkisar antara 159,68 - 173,80 cm, kedelai berkisar 44,79 - 46,30 $\mathrm{cm}$ dan perlakuan kombinasi berkisar 165,26-184,19 cm (sorgum) dan 7,27 - 10,96 $\mathrm{cm}$ (kedelai) (Tabel 3). Pada TBM 3, tinggi tanaman tumpangsari sorgum berkisar antara 93,10 - 94,58 cm, kedelai berkisar $51,92-84,96 \mathrm{~cm}$ dan perlakuan kombinasi berkisar 115,66 - 125,74 cm (sorgum) dan 59,09-66,55 cm (kedelai) (Tabel 4).
Rataan intensitas cahaya di TBM 3 sebesar 405,00 lux dan di TBM 1 sebesar 56.600,00 lux merupakan salah satu faktor yang menyebabkan terjadinya perbedaan nyata antara pertumbuhan tanaman tumpangsari di TBM 1 dan TBM 3. Faktor lainnya yang menyebabkan hal demikian adalah kondisi lahan yang kering karena waktu penanaman dilakukan pada saat curah hujan dan hari hujan yang cukup rendah yakni $29 \mathrm{~mm}$ dengan 7 hari hujan (Gambar 3). Pada perlakuan kombinasi, populasi tanaman kedelai mengalami penurunan populasi karena banyaknya tanaman yang mati karena naungan sorgum dan kekeringan. Adanya naungan kanopi dari tanaman yang lebih tinggi menyebabkan cahaya menjadi kendala utama atau faktor pembatas bagi pertumbuhan dan perkembangan kedelai. Meskipun demikian pertumbuhan sorgum masih relatif tumbuh normal di kondisi ini (Gambar 5). 


\section{Bobot Kering (Produksi) Tanaman Tumpangsari Sorgum dan Kedelai di Gawangan Karet}

Hasil penelitian menunjukkan bahwa perlakuan tumpangsari sorgum dan kedelai pada jarak 0,5 m dari tanaman karet memberikan produksi lebih tinggi di TBM 1 sebesar 762,04 kg dan 710,96 kg (Tabel 5). Hal ini dikarenakan pemanfaatan lahan yang optimal dengan jarak yang relatif lebih dekat dengan tanaman utama dan berbeda nyata dengan perlakuan lainnya pada jarak $1 \mathrm{~m}$ dan 1,5 m. Pada perlakuan kombinasi menunjukkan produksi sorgum lebih tinggi dibandingkan dengan kedelai karena terjadi persaingan pertumbuhan dalam hal penyerapan hara dan intensitas cahaya

Pada TBM 3, perlakuan tumpangsari sorgum dan kedelai dengan jarak 0,5 m dari tanaman utama tetap menunjukkan produksi lebih tinggi dibandingkan perlakuan dengan jarak lainnya yaitu sebesar 301,85 kg dan 20,47 kg (Tabel 6).

Perlakuan tumpangsari kedelai, sorgum, dan kombinasinya di TBM 1 memberikan produksi lebih tinggi jika dibandingkan perlakuan tumpangsari di TBM 3. Produksi yang lebih tinggi di TBM 1 disebabkan karena penyerapan air dan penimbunan hasil fotosintesis lebih tinggi daripada di TBM 3 yang ternaungi oleh tanaman karet. Secara umum karakter tanaman yang terkena langsung cahaya berbeda dalam hal struktur, biokimia dan perubahan gas dibandingkan tanaman yang ternaung (Lambers, Chapin, \& Pons, 1998).

Tanaman tumpangsari yang terkena cahaya menunjukkan berat kering biomassa yang tinggi, daun lebih tebal, dibandingkan tanaman yang ternaung. Lambers et al. (1998) menyebutkan bahwa kandungan klorofil tinggi, transport elektron, kapasitas fotosintesis dan kapasitas karbisilasi juga lebih tinggi pada tanaman yang terkena cahaya langsung (Lambers et al. 1998). Kondisi tersebut sangat besar berpengaruh dalam berbagai proses fisiologi di dalam jaringan tanaman yang berujung pada gangguan pertumbuhan dan produksi (Karamoy, 2009).

\section{Analisa Tanah}

Berdasarkan hasil analisa tanah dari lahan TBM 1 dan TBM 3 pra tumpangsari menunjukkan bahwa kondisi tanah di lahan tersebut memiliki tingkat kesuburan yang tergolong rendah dan tingkat kemasaman

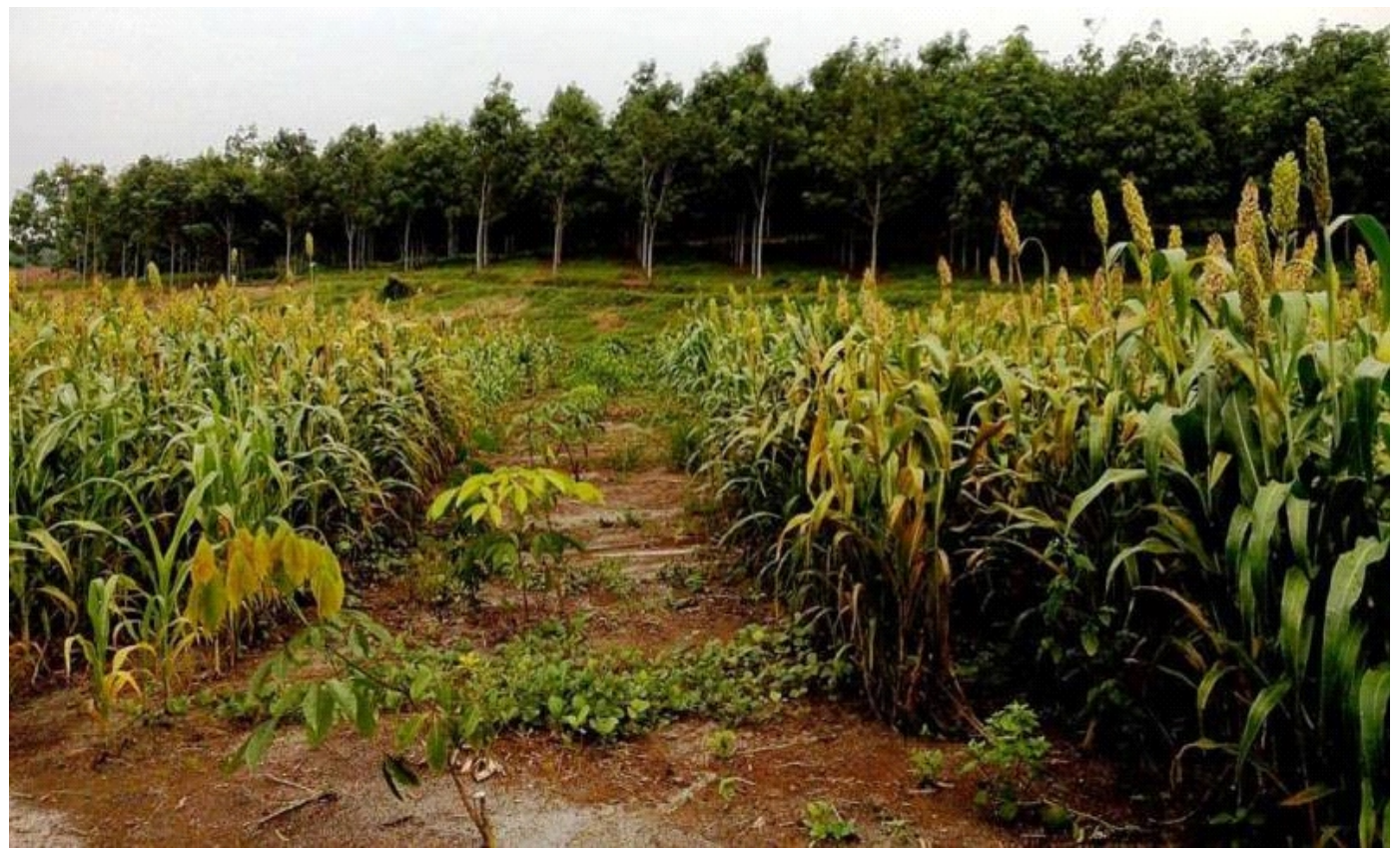

Gambar 5. Tanaman tumpangsari sorgum di gawangan TBM 1

Figure 5. Intercropping sorghum in the space of Immature Rubber year 1 
Tabel 5. Bobot kering tanaman tumpangsari pada TBM 1

Table 5. Dry weight intercropping in Immature Rubber year 1

\begin{tabular}{|c|c|c|c|c|}
\hline \multirow{2}{*}{$\begin{array}{l}\text { Perlakuan } \\
\text { Treatments }\end{array}$} & \multirow{2}{*}{$\begin{array}{l}\text { Sorgum } \\
\text { Sorghum } \\
\text { (kg) }\end{array}$} & \multirow{2}{*}{$\begin{array}{l}\text { Kedelai } \\
\text { Soybean } \\
\text { (kg) }\end{array}$} & \multicolumn{2}{|c|}{$\begin{array}{c}\text { Kombinasi } \\
\text { Combination } \\
(\mathrm{kg})\end{array}$} \\
\hline & & & $\begin{array}{l}\text { Sorgum } \\
\text { Sorghum }\end{array}$ & $\begin{array}{l}\text { Kedelai } \\
\text { Soybean }\end{array}$ \\
\hline $0.5 \mathrm{~m}$ & $762,04 \mathrm{~b}$ & $710,96 \mathrm{c}$ & $698,15 c$ & $11,07 \mathrm{c}$ \\
\hline $1 \mathrm{~m}$ & $742,59 \mathrm{~b}$ & $671,30 \mathrm{~b}$ & $601,85 \mathrm{~b}$ & $7,69 \mathrm{~b}$ \\
\hline $1.5 \mathrm{~m}$ & $565,74 \mathrm{a}$ & $617,75 \mathrm{a}$ & $536,11 \mathrm{a}$ & $4,84 \mathrm{a}$ \\
\hline
\end{tabular}

Angka-angka yang diikuti oleh huruf yang berbeda pada kolom yang sama berbeda nyata pada Uji Jarak Berganda Duncan pada taraf $5 \%$

Figures followed by different letter in the same column are significantly different based on Duncan multiple range test at $5 \%$ significant level

Tabel 6. Bobot kering tanaman tumpangsari pada TBM 3

Table 6. Dry weight intercropping in Immature Rubber year 3

\begin{tabular}{|c|c|c|c|c|}
\hline \multirow{2}{*}{$\begin{array}{l}\text { Perlakuan } \\
\text { Treatments }\end{array}$} & \multirow{2}{*}{$\begin{array}{l}\text { Sorgum } \\
\text { Sorghum } \\
\quad(\mathrm{kg})\end{array}$} & \multirow{2}{*}{$\begin{array}{l}\text { Kedelai } \\
\text { Soybean } \\
(\mathrm{kg})\end{array}$} & \multicolumn{2}{|c|}{$\begin{array}{c}\text { Kombinasi } \\
\text { Combination } \\
\text { (kg) }\end{array}$} \\
\hline & & & $\begin{array}{l}\text { Sorgum } \\
\text { Sorghum }\end{array}$ & $\begin{array}{l}\text { Kedelai } \\
\text { Soybean }\end{array}$ \\
\hline $0.5 \mathrm{~m}$ & $301,85 \mathrm{c}$ & $20,47 \mathrm{c}$ & $224,38 \mathrm{c}$ & $2,24 \mathrm{c}$ \\
\hline $1 \mathrm{~m}$ & $261,42 \mathrm{~b}$ & $17,90 \mathrm{~b}$ & $185,19 \mathrm{~b}$ & $1,98 \mathrm{~b}$ \\
\hline $1.5 \mathrm{~m}$ & $187,41 \mathrm{a}$ & $12,80 \mathrm{a}$ & $155,25 \mathrm{a}$ & $1,31 \mathrm{a}$ \\
\hline
\end{tabular}

Angka-angka yang diikuti oleh huruf yang berbeda pada kolom yang sama berbeda nyata pada Uji Jarak Berganda Duncan pada taraf $5 \%$

Figures followed by different letter in the same column are significantly different based on Duncan multiple range test at $5 \%$ significant level

yang tinggi (TBM $1 \mathrm{pH}=4,2$ dan TBM $3 \mathrm{pH}=$ 4,4) (Tabel 4). Menurut Wang \& Gaston (2014), pH mengganggu serapan unsur hara dan pertumbuhan tanaman melalui ketersediaan unsur hara dan unsur yang bersifat racun bagi tanaman. Pada tanah yang memiliki $\mathrm{pH}$ rendah, seperti di TBM 1 dan TBM 3 unsur hara $P$ sulit diserap tanaman karena diikat oleh aluminium (Al). Selain itu kandungan unsur haranya yang sangat rendah terutama terlihat pada nitrogen, fosfat, dan kalium rendah, kapasitas tukar kation (KTK) dan kejenuhan basa juga rendah.

Perlakuan tumpangsari menunjukkan peningkatan $\mathrm{pH}$, unsur hara, maupun KTK. Perbaikan kondisi tanah tersebut menjadi sangat penting, karena kekhawatiran bahwa tumpangsari merugikan tanaman utama tidak terbukti. Meskipun demikian peningkatan tersebut belum mencapai kondisi yang optimal untuk pertanian. Ideal $\mathrm{pH}$ tanah untuk pertanian memiliki kisaran pH 5,5 - 6,7. Pada kondisi tersebut unsur hara dalam kondisi mudah diserap tanaman (Yuwana, 2009).

Perlakuan tumpangsari juga diharapkan meningkatkan kandungan unsur hara penting di dalam tanah. Dari hasil analisis tanah kandungan $\mathrm{N}, \mathrm{P}$, dan $\mathrm{K}$ meningkat setelah perlakuan tumpangsari. Meskipun cenderung meningkat, ketersediaan $\mathrm{N}$ setelah perlakuan tumpangsari di TBM 1 dan TBM 3 belum menunjukkan perubahan yang nyata yaitu berkisar 1 - 3\%. Beberapa penelitian menyebutkan bahwa penanaman tanaman legume akan membantu meningkatkan $\mathrm{N}$ di dalam tanah (Zahran, 1999). Seperti halnya tanaman legume, tanaman kedelai dikaitkan dengan kemampuan mengikat nitrogen $\left(\mathrm{N}_{2}\right)$ di atmosfer melalui aktivitas bakteri 
Tabel 7. Perubahan sifat kimia dan fisik tanah areal TBM 1 dan TBM 3 sebelum dan sesudah penanaman tumpangsari.

Table 7. Changing of the chemical and physical properties of soil at Immature Rubber year 1 and Immature Rubber year 3 areas before and after intercropping planting.

\begin{tabular}{|c|c|c|c|c|c|c|c|c|c|c|}
\hline \multirow{2}{*}{$\begin{array}{c}\text { Jenis } \\
\text { Analisis } \\
\text { Type of } \\
\text { analysis }\end{array}$} & \multicolumn{5}{|c|}{$\begin{array}{c}\text { TBM } 1 \\
\text { Immature Rubber year } 1\end{array}$} & \multicolumn{5}{|c|}{$\begin{array}{c}\text { TBM } 3 \\
\text { Immature Rubber year } 3\end{array}$} \\
\hline & $\begin{array}{l}\text { Kondisi } \\
\text { awal } \\
\text { Pre } \\
\text { condition }\end{array}$ & $\begin{array}{l}\text { Kontrol } \\
\text { Control }\end{array}$ & $\begin{array}{l}\text { Sorgum } \\
\text { Sorghum }\end{array}$ & $\begin{array}{l}\text { Kedelai } \\
\text { Soybean }\end{array}$ & $\begin{array}{c}\text { Kombinasi } \\
\text { Combina } \\
\text { tion }\end{array}$ & $\begin{array}{c}\text { Kondisi } \\
\text { awal } \\
\text { Pre } \\
\text { condition }\end{array}$ & $\begin{array}{l}\text { Kontrol } \\
\text { Control }\end{array}$ & $\begin{array}{l}\text { Sorgum } \\
\text { Sorghum }\end{array}$ & $\begin{array}{l}\text { Kedelai } \\
\text { Soybean }\end{array}$ & $\begin{array}{c}\text { Kombi } \\
\text { nasi } \\
\text { Combina } \\
\text { tion }\end{array}$ \\
\hline $\mathrm{pH}$ & 4.2 & 4,40 & 5,59 & 4,54 & 5,01 & 4.4 & 3,66 & 5,10 & 5,24 & 5,01 \\
\hline C (\%) & 1.27 & 0,76 & 1,15 & 1,34 & 1,40 & 1.22 & 1,13 & 1,12 & 1,23 & 1,03 \\
\hline $\mathrm{N}(\%)$ & 0.13 & 0,12 & 0,13 & 0,16 & 0,16 & 0.13 & 0,14 & 0,13 & 0,15 & 0,16 \\
\hline $\mathrm{C} / \mathrm{N}$ rasio & 9,8 & 6,3 & 8,8 & 8,4 & & & & & & \\
\hline $\begin{array}{l}\mathrm{P}_{2} \mathrm{O}_{5}- \\
\text { Total } \\
\text { (mg/100 g) }\end{array}$ & 11 & 10,26 & 20,15 & 32,37 & 13,34 & 13 & 23,38 & 20,15 & 23,81 & 18,06 \\
\hline $\begin{array}{l}\mathrm{P}_{2} \mathrm{O}_{5} \mathrm{Bray} \\
1 \text { (ppm) }\end{array}$ & 5,3 & 2,24 & 3,08 & 1,37 & 4,26 & 4,9 & 2,55 & 3,08 & 2,49 & 2,09 \\
\hline $\begin{array}{l}\mathrm{K}_{2} \mathrm{O} \\
(\mathrm{mg} / 100 \mathrm{~g})\end{array}$ & 42 & 26,97 & 26,22 & 66,2 & 28,05 & 151 & 79,02 & 92,78 & 99,54 & 88,00 \\
\hline $\begin{array}{l}\mathrm{Mg} \\
(\mathrm{cmol}(+) / \mathrm{kg})\end{array}$ & 0,63 & 0,15 & 0,90 & 0,58 & 0,81 & 0,48 & 0,50 & 0,31 & 0,41 & 0,31 \\
\hline $\begin{array}{l}\text { KTK } \\
\left.\left(\mathrm{cmol}^{+}\right) / \mathrm{kg}\right)\end{array}$ & 8,28 & 13,25 & 18,66 & 14,38 & 19,78 & 7,54 & 10,80 & 11,56 & 12,04 & 12,67 \\
\hline
\end{tabular}

Rhizobium japanicum. Bakteri ini bersimbiosis di dalam akar kacang dengan membentuk nodula atau bintil akar. Adanya bintil (nodul) ini akan memberikan keuntungan dalam memfiksasi nitrogen dalam tanah serta meningkatkan kesuburan tanah. Jumlah nitrogen yang difiksasi pada tanaman kedelai $33 \%$ dari $\mathrm{N}$ total tanaman yang setara dengan $26-33 \mathrm{~kg} / \mathrm{N} / \mathrm{Ha} /$ musim (Watkins et al., 2012). Nitrogen yang difiksasi kedelai dapat dilepaskan ke tanah jika biomasa kedelai dikomposkan di areal TBM tersebut sehingga kandungan akan meningkat.

Kandungan $\mathrm{P}$ total dan $\mathrm{K}$ meningkat yang diduga dikarenakan perlakuan pemupukan selama budidaya tumpangsari. Sementara itu, kandungan P yang tersedia di areal tanaman sorgum dan kombinasi sorgum kedelai lebih tinggi dibandingkan areal kedelai saja. Meskipun $P$ total meningkat, tetapi $\mathrm{P}$ yang tersedia justru turun. Sawers et al. (2008) melaporkan bahwa kandungan $\mathrm{P}$ tersedia di dalam rhizosfer tanaman sorgum meningkat setelah 30 hari kemudian turun setelah 60 hari. Hal ini dikarenakan P yang tersedia di dalam tanah diserap oleh tumpangsari. Kemampuan menyerap P dikaitkan dengan simbiosis antara sorgum dengan mikoriza. Meenakshisundaram \& Santhaguru (2011) menyebutkan bahwa inokulasi dengan Mikoriza arbuskular meningkatkan kandungan $\mathrm{P}$ di dalam jaringan sorgum.

Selain peningkatan $\mathrm{P}$ dan $\mathrm{N}$, KTK juga mengalami perubahan. KTK memberi gambaran tentang kemampuan tanah memegang hara untuk dapat dipertukarkan. Nilai kisaran KTK pada penelitian ini antara 7,54 - 19,78 $\mathrm{cmol}^{+} / \mathrm{kg}$, sedangkan kisaran normal KTK berada di $20-40\left(\mathrm{cmol}^{+} / \mathrm{kg}\right)$ (Yuwana, 2009). Perlakuan tumpangsari merubah KTK menjadi lebih tinggi dibandingkan areal tanpa tumpangsari. Pada areal yang ditanam kombinasi antara sorgum dan kedelai mempunyai KTK paling tinggi dibandingkan perlakuan lainnya. Tinggi rendahnya KTK tanah sangat terkait dengan jenis mineral liat dan kandungan bahan organik di dalam tanah serta $\mathrm{pH}$ tanah (Suharta, 2010). Tanah dengan KTK yang tinggi mampu menjerap dan menyediakan unsur hara lebih baik daripada tanah dengan KTK rendah. Hal ini dikarenakan unsur hara terdapat dalam bentuk kompleks jerapan koloid sehingga unsur hara tersebut tidak mudah hilang tercuci oleh air (Hardjowigeno, 1989). Pada tanah yang mempunyai KTK rendah, bahan organik (C-organik) menjadi sangat penting dalam meningkatkan nilai KTK tanah. Perbaikan tanah akan semakin meningkat 
apabila biomasa sisa hasil panen dikembalikan ke areal penanaman. Kertonegoro, Shiddieq, Sulakhudin, dan Dariah, (2007) juga melaporkan bahwa penambahan bahan organik dapat memperbaiki sifat-sifat fisik dan kimia tanah di areal yang berpasir.

\section{Analisis Finansial Tanaman Tumpangsari Sorgum dan Kedelai}

Produksi tanaman tumpangsari kedelai (tunggal) di lahan gawangan karet umur TBM 1 menunjukkan hasil yang menguntungkan dengan tingkat $R / C$ ratio sebesar 1,39. Keuntungan yang diperoleh dengan tingkat harga sebesar IDR 8.500,/Kg mencapai IDR 4.800.000,-. Produksi kedelai pada TBM 1 dan 3 masing-masing sebesar $2.000 \mathrm{Kg}$ dan $51 \mathrm{Kg}$. Faktor intensitas cahaya akibat naungan tanaman karet pada TBM 3 diperkirakan menjadi kendala utama yang menyebabkan produksi kedelai pada TBM 3 sangat kecil. Tabel 5 memperlihatkan analisis finansial intercropping sorgum dan kedelai.

Demikian halnya dengan intercropping sorgum. Penanaman sorgum (tunggal) pada TBM 1 memberikan hasil yang menguntungkan, dimana $R / C$ ratio yang diperoleh mencapai 1,24 . Keuntungan yang diperoleh dengan tingkat harga sebesar IDR $7.000,-/ \mathrm{Kg}$ adalah IDR 2.792.593,-. Perlakuan tanaman sorgum pada TBM 3 (tunggal) memperlihatkan hasil produksi yang lebih rendah $(751 \mathrm{Kg})$. Faktor intensitas cahaya (naungan tanaman karet) juga diperkirakan menjadi penyebab rendahnya pencapaian produksi tersebut.

Perlakuan kombinasi (sorgum + kedelai) pada kedua umur tanaman karet (TBM 1 dan TBM 3) menunjukkan hasil yang sangat rendah. Perebutan unsur hara pada TBM 1 diperkirakan menjadi kendala produksi. Sementara pada TBM 3 selain perebutan unsur hara, intensitas cahaya juga diperkirakan menjadi kendala. Produksi pada TBM 1 hanya mencapai 1.836 kg untuk sorgum dan $24 \mathrm{~kg}$ untuk kedelai, sementara produksi pada TBM 3 hanya mencapai $565 \mathrm{~kg}$ untuk sorgum dan $6 \mathrm{~kg}$ untuk kedelai.

Analisis di atas memperlihatkan bahwa pemanfaatan lahan gawangan karet untuk penanaman sorgum dan kedelai menguntungkan pada TBM 1, dimana intensitas cahaya matahari masih cukup tinggi di areal gawangan karet. Seiring dengan peningkatan usia tanaman utama (karet) maka intensitas cahaya matahari pada areal gawangan semakin menurun, sehingga potensi intercropping sorgum dan kedelai pun semakin menurun. Pengaruh intensitas cahaya terhadap potensi produksi tanaman intercropping.

\section{KESIMPULAN}

Pertumbuhan tanaman karet tidak terhambat dengan adanya tanaman

Tabel 8. Asumsi analisa finansial tanaman tumpangsari sorgum dan kedelai dalam hektar Table 8. Assuming financial analysis of intercropping sorghum and soybean in hectare

\begin{tabular}{|c|c|c|c|c|c|c|c|c|}
\hline \multirow{3}{*}{$\begin{array}{c}\text { Uraian } \\
\text { Descriptions }\end{array}$} & \multicolumn{4}{|c|}{ Perlakuan TBM 1 (Treatment of IRP 1) } & \multicolumn{4}{|c|}{ Perlakuan TBM 3 (Treatment of IRP 3) } \\
\hline & \multirow{2}{*}{$\begin{array}{l}\text { Sorgum } \\
\text { Sorghum }\end{array}$} & \multirow{2}{*}{$\begin{array}{c}\text { Kedele } \\
\text { Soybean }\end{array}$} & \multicolumn{2}{|c|}{ Kombinasi (Combination) } & \multirow{2}{*}{$\begin{array}{l}\text { Sorgum } \\
\text { Sorghum }\end{array}$} & \multirow{2}{*}{$\begin{array}{c}\text { Kedele } \\
\text { Soybean }\end{array}$} & \multicolumn{2}{|c|}{ Kombinasi (Combination) } \\
\hline & & & Sorgum & Kedele & & & Sorgum & Kedele \\
\hline \multicolumn{9}{|l|}{ Biaya operasional } \\
\hline - Alat dan bahan & 6.300 .000 & 6.800 .000 & & 9.700 .000 & 7.800 .000 & 8.300 .000 & & 11.950 .000 \\
\hline - Tenaga kerja & 5.400 .000 & 5.400 .000 & & 5.400 .000 & 5.400 .000 & 5.400 .000 & & 5.400 .000 \\
\hline Total biaya & 11.700 .000 & 12.200 .000 & & 15.100 .000 & 13.200 .000 & 13.700 .000 & & 17.350 .000 \\
\hline Produksi & 2.070 & 2.000 & 1.836 & 24 & 751 & 51 & 565 & 6 \\
\hline Harga komoditas & 7.000 & 8.500 & 7.000 & 8.500 & 7.000 & 8.500 & 7.000 & 8.500 \\
\hline Pendapatan & 14.492 .593 & 17.000 .000 & 12.852 .778 & 200.545 & 5.254 .753 & 434.969 & 3.953 .704 & 47.065 \\
\hline Pendapatan bersih & 2.792 .593 & 4.800 .000 & & $(2.046 .677)$ & $(7.945 .247)$ & $(13.265 .031)$ & & $(13.349 .231)$ \\
\hline $\mathrm{R} / \mathrm{C}$ ratio & 1,24 & 1,39 & & $0,86^{\prime}$ & 0,40 & 0,03 & & 0,23 \\
\hline
\end{tabular}


tumpangsari sorgum dan kedelai. Hasil penelitian menunjukkan bahwa tanaman tumpangsari dapat tumbuh normal di areal gawangan TBM 1, sedangkan di TBM 3 pertumbuhannya sangat terhambat. Dengan adanya tanaman tumpangsari sorgum dan kedelai meningkatkan kandungan $\mathrm{P}, \mathrm{N}, \mathrm{pH}$ dan $\mathrm{KTK}$, serta dapat menghambat perkembangan jamur akar putih (Rigidoporus microporus). Berdasarkan hasil produksi menunjukkan bahwa pola tanam kedelai dan sorgum terbaik terdapat pada jarak tanam 0,5 $\mathrm{m}$ dari tanaman karet dan secara ekonomi tumpangsari sorgum dan kedelai pada TBM 1 memberikan keuntungan, dimana $\mathrm{R} / \mathrm{C}$ ratio dari kedua perlakuan tersebut masing-masing mencapai 1,24 dan 1,39. Untuk penelitian selanjutnya diharapkan untuk memperhatikan musim tanam agar produksi dapat optimal.

\section{UCAPAN TERIMA KASIH}

Pada kesempatan ini disampaikan terima kasih kepada Badan Penelitian dan Pengembangan Pertanian atas pemberian dana KKP3N 2013 dengan nomor kontrak: 776/LB.620/I.1/2/2013.

\section{DAFTAR PUSTAKA}

Benhamou, N., Belanger, R. R., \& Paulitz, T. C. (1996). Induction of differential host responses by Pseudomonas fluorescens in Ri T-DNA - transformed pes roots after challenge with Fusarium oxysporum f. Sp. pisi and Pythium ultimum. Bioch. and Cell Biol, 86(11), $1174-1185$.

Borrell, A., \& Hammer, G. (2005). The physiology of "stay-green" in sorghum. Brisbane, Australia: University of Quensland.
Cazorla, F. M., Duckett, S. B., Bergstrom, E. T., Noreen, S., Odijk, R., Lugtenberg, B. J., Thomas-Oates, J. E., \& Bloemberg, G. V. (2006). Biocontrol of avocado Dematophora root rot by antagonistic Pseudomonas flourescens PCL 1606 correlates with the production of 2-Hexyl 5-propyl resorcinol. Mol Plant Microbe Interact., 19(4), 418-428. Doi: 10.1094/MPMI19-0418.

Fairuzah, Z., Dalimunthe, C. I., Karyudi, Suryaman, S., \& Widhayati, W. E. (2014). Keefektifan beberapa fungi antagonis (Trichoderma sp.) dalam biofungisida Endohevea terhadap penyakit jamur akar putih (Rigidoporus microporus) di lapangan. Jurnal Penelitian Karet, 32(2), 198205.

Giehl, R. F., \& Von Wiren, N. (2014). Root nutrient foraging. Plant Physiol., $166(2), 509-517$. Doi : $10.1104 /$ pp. 114.245225 .

Hardjowigeno, S. (1989). Ilmu Tanah. Jakarta, Indonesia: PT. Mediyatama Sarana Perkasa.

Idoko, S. O., Ehigiator, J. O., Esekhade, T. U., \& Orimoloyo, J. R. (2012). Rubber, maize and cassava Intercropping systems on rehabilitated rubber plantation soil in south eastern Nigeria. J. of Agric. and Biodiv. Res., $1(6), 97-101$

Jayaratna R., Liyanage, A. S., \& Pahalawattaarachchi, W. (1986). Effect of VA micorrhizae (Giganspora margarita) on white root disease resistance in Pueraria phaseoloides and Hevea brasiliensis seedlings. Rubb. Res. Inst. Sri Langka, 65, 22 - 31. 
Jumingan. (2011). Studi Kelayakan Bisnis: Teori dan Pembuatan Proposal Kelayakan. Jakarta, Indonesia: Bumi Aksara.

Karamoy, L. T. (2004). The effect of soil cultivation and leguminosa planting on the N P and K levels of marginal land. Eugenia, 10(1), 71-75.

Karamoy, L. T. (2009). Hubungan iklim dengan pertumbuhan kedelai (relationship between climate and soybean (Glicine max (L) Merrill) Growth). Soil Environment, 7(1), 6568.

Kertonegoro, B. K., Shiddieq, D., Sulakhudin., \& Dariah, A. (2007). Optimalisasi lahan pasir pantai bugel kulon progo untuk pengembangan tanaman hortikultura dengan teknologi inovatif berkearifan lokal. Prosiding Seminar Nasional Sumberdaya Lahan dan Lingkungan Pertanian. Bogor, Indonesia: Balai Besar Litbang Sumberdaya Lahan Pertanian.

Khaosaad, T., Garcia-Garrido, J. M., Steinkellner S., \& Vierheilig, H. (2007). Take-all disease is systemically reduced in roots of mycorrhizal barley plants. Soil Biol. and Bichem, 39(3), 727 - 734. Doi: 10.1016/j.soilbio.2006.09.014.

Lambers, H., Chapin, F. S., \& Pons, T. L. (1998). Plant physiological ecology. New York, USA: Springer-Verlag.

Linderman, R. G. (1996). Role of VAM fungi in biocontrol. In F. L. Pfleger \& R. G. Linderman (Eds.). Mycorrhyzae and Plant Health. (pp.1-25) Minnesota, USA: APS Press. St. Paul.

Martin, F. M., Perotto, S., \& Bonfante, P. (2007). Mycorrhizal fungi: A fungal community at the interface between soil and roots. In $\mathrm{R}$. Pinton, $\mathrm{Z}$. Varanini, \& P. Nannipieri. The Rizosphere: the Soil-Plant Interface. Biochemistry and Oragnic Substances (pp. 201-236). London, United Kingdom: CRS Press.
Meenakshisundaram, M., \& Santhaguru, K. (2011). Studies on association of arbuscular mycorrhizal fungi with Gluconacetobcter diazotrophicus and its effect on improvement of Sorghum bicolor (L.). Int J Cur Sci Res., 1(2), 23-30.

Nugroho, P. A., Istianto., Siagian, N., \& Karyudi. (2010). Pengaruh penanaman Mucuna bracteata terhadap status hara dan pertumbuhan tanaman karet belum menghasilkan. Jurnal Penelitian Karet, 28(1), 44-54.

Ogwuche, P., Umar, H. Y., Esekhade, T. U., $\&$ Franscis, S. Y. (2012). Economic of intercropping natural rubber with arable crops: A Panacea for poverty allevation of rubber farmers. J. Agric. Soc. Sci., 8, 100-102.

Rahayu, S., Pawirosoemardjo, S., \& Sujatno. (2007). Biological control of white root disease of hevea rubber using Trichoderma based Biofungicide Triko $\mathrm{SP}^{\text {plus }}$. Proc. International Workshop on white root disease of hevea rubber (pp. 110126). Salatiga, Indonesia: IRRDB.

Sawers, R. J. H., Yang, S. Y., Gutjahr, C., \& Paszkowski, U. (2008). The molecular components of nutrient exchange in arbuscular mycorrhizal interactions. In Z. A. Siddiqui, M. S. Akhtar, \& K. Futai. Mycorrrhizae : sustainable agriculture and forestry (pp. 37-60). Springer Science + Business Media B.V.

Suharta, N. (2010). Karakteristik dan permasalahan tanah marginal dari batuan sedimen masam di Kalimantan. Jurnal Litbang Pertanian, 29(4), 139-146.

Supriadi, M. (2009). Implementasi model peremajaan partisipatif dalam program revitalisasi perkebunan karet. Warta Perkaretan, 28(1), 7686. 
Toure, A., \& Weltzien, E. (2004). Guinea sorghum hybrids: bringing the benefits of hybrid technology to a staple crop of sub-Saharan Africa. IER-ICRISAT.

Wang, J. J., \& Gaston, L. A. (2014). Nutrient chemistry of manure and manure-impacted soils as influenced by application of bauxite residue. In J. J. Wang \& L. A. Gaston L.A (eds). Applied Manure and Nutrient Chemistry for Sustainable Agriculture and Environment (pp. 339-366). New York, USA: Springer Dordrecht Heidelberg. Doi: 10.1007/978-94017-8807-6
Watkins, M., Castlehouse, H., Hannah, M. M., \& Nash, D. M. (2012). Nitrogen and phosphorus changes in soil and soil water after cultivation. Applied and Envirenmental Soil Science, 10 $\mathrm{h}$ a 1 a $\mathrm{m}$ a $\mathrm{n}$. Doi:10.1155/2012/157068: 10 pages

Yuwana, N. W. (2009). Membangun kesuburan tanah di lahan marjinal. J. Mmu Tanah dan Lingkungan, 9(2), 137-141.

Zahran, H. M. (1999). Rhizobium-legume symbiosis and nitrogen fixation under severe conditions and in an arid climate. Microb. and $\mathrm{Mol}$ Biol. Rev., 63(4), 968-989. 